\title{
Biodiversity of polychaetous annelids from the peninsula of Cap Bon, northeast coast of Tunisia
}

\author{
SANA ZAÂBI ${ }^{1,4}$, PATRICK GILLET ${ }^{2}$, AHMED AFLI $^{1} \&$ MONCEF BOUMAIZA $^{3}$ \\ ${ }^{\prime}$ Laboratoire de Biodiversité et Valorisation des Bio-ressources Aquatiques. Institut National des Sciences et Technologies de la Mer, \\ Salammbô, Tunisia, E-mail: zaabi.sana@yahoo.fr \\ ${ }^{2}$ Centre d'Etude et de Recherche sur les Ecosystèmes Aquatiques, Institut de Biologie et d'Ecologie Appliquée, UCO. 44 rue Rabelais \\ 49000 Angers, France, E-mail: patrick.gillet@uco.fr \\ ${ }^{3}$ Unité d'Hydrobiologie Littorale et Limnique, Faculté des Sciences de Bizerte, Tunisia. \\ ${ }^{4}$ Corresponding author.
}

\begin{abstract}
In Tunisia, polychaete studies are very rare (Fauvel 1924 a, b; Westheide 1972; Zibrowius 1970, 1971; Cantone 1978; Ben Amor 1984; Zaâbi \& Afli 2005). The aim of this study was to update and fill in gaps in data of polychaetes of Tunisia. Samples were taken aboard the research vessel R/V Hannibal with a Van Veen grab (0.1 $\mathrm{m}^{2}$ ) and a core $\left(0.009 \mathrm{~m}^{2}\right)$. Nine sites located on the peninsula of Cap Bon on the NE coast of Tunisia, from Sidi Daoud to Ras Lahmer, were sampled in 2005 and 2006. A total of 5,920 individuals in 29 families and 88 species of polychaetes were identified. Twenty-nine species were newly recorded for Tunisia, including the ampharetid Isolda pulchella O.F. Müller, 1858 and the paraonid Aricidea cerrutii (Laubier, 1966). Diversity parameters were established. Abundance and species richness were higher in shallow waters dominated by Protodorvillea kefersteini (McIntosh, 1869) and Malacoceros fuliginosus (Claparède, 1868) than in deep waters where Aponuphis fauveli (Rioja, 1918) and Euclymene palermitana (Grube, 1840) dominated. Multivariate methods, including the Shannon diversity index, cluster analysis, and rank frequency analysis, were used to characterize the spatial structure and temporal variability of the different communities.
\end{abstract}

Key words: polychaetes, biodiversity, Tunisia, Mediterranean

\section{Introduction}

There have been very few polychaete studies in Tunisia, with the most important being Fauvel (1924 a-b), Zibrowius (1970, 1971), Westheide (1972), Cantone (1978) and Bouderesque (1997). Zghal \& Ben Amor (1980) collected data on Tunisian polychaetes and listed 222 species. Later, Zghal \& Azzouna (1982) added seven additional species. Subsequently, Zaâbi \& Afli (2005) studied the distribution of polychaetes along the northeastern coast of the Tunis Gulf. Several taxonomic and ecological works have been undertaken on other Tunisian macrobenthic fauna. Azzouz (1971) described the benthic fauna of north and southeast Tunisia; Ben Alaya (1972) studied the fauna associated with Posidonia oceanica in the Gulf of Tunis; Zaouali \& Baeten (1985) studied the macrobenthic community in Bibans lagoon; Ben Mustapha et al. (2003) documented sponges from Tunisian coasts; Ayari \& Afli (2003) surveyed the macrobenthic fauna in Tunis Bay, and Mestiri et al. (2005) worked on ascidians collected from Zembra-Zembretta Island. However, there is an obvious lack of ecological studies of polychaetes. The objective of this paper is to characterize the 
structure and distribution of the polychaete fauna on the eastern coast of Tunisia. This paper is part of the research framework MORGEN (Modèle et Outils de Recherche sur les Gisements des Ecosystèmes coralligènes du Nord).

\section{Materials and methods}

Sampling and laboratory procedures. The study area at Sidi Daoud is situated in the NE Tunisian gulf and NW of Cap Bon, in a large bay with a width of $2 \mathrm{~km}$ and a depth of $1300 \mathrm{~m}$ (Fig. 1). It is an important bay between Ras el Fartas and Cap Bon. The Sidi Daoud area has a Mediterranean climate characterized by irregular precipitation with an average annual rainfall of $500 \mathrm{~mm}$ (Ben Salem 2000). The air temperature in Sidi Daoud's bay varies from 13 to $27^{\circ} \mathrm{C}$ (Ben Alaya 1972).

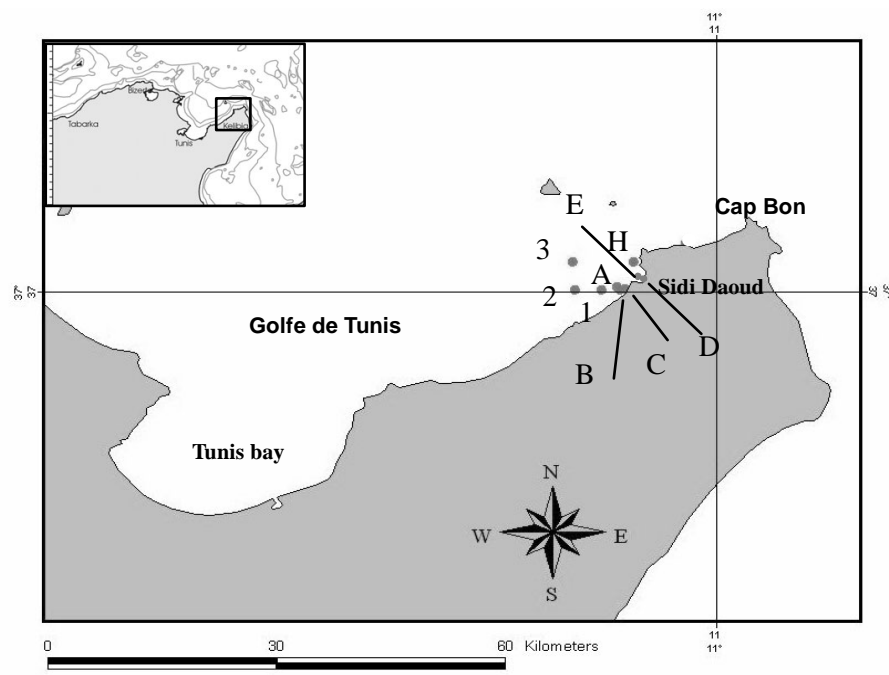

FIGURE 1. Map of the investigated area with location of the nine sampling sites from Sidi Daoud, Tunisia.

According to Lubet \& Azzouz (1969), the bottom sediment type is influenced by geographical and hydrological conditions. The study site is a bay protected from the hydrodynamic conditions of the Mediterranean.

The polychaete fauna was sampled at nine sites (Fig. 1) during summer, autumn, and spring from 2005 to 2006. Station depths varied from 2-60 m (Table 1). Aboard the R/V Hannibal, a Van Veen grab $\left(0.1 \mathrm{~m}^{2}\right)$ was used for the deep sites (1-3), and a cylindrical core for shallow sites (A-E and H). Samples were washed through a 1-mm-mesh sieve and fixed in $7 \%$ sea water formaldehyde for identification. In the laboratory, samples were rinsed in fresh water and preserved in $70 \%$ ethanol and the polychaetes were identified to species and counted. Polychaetes were identified using various guides, e.g., Fauvel (1923, 1927) and Fauchald (1977), and other papers for specific-level identification.

An additional sediment sample (100 g) was also taken at each site to measure particle grain size. These samples were dried for $48 \mathrm{~h}$ at $60^{\circ} \mathrm{C}$, and then washed through a $63-\mu \mathrm{m}$-mesh sieve in order to separate the small (silt + clay) fraction (Afli \& Chenier 2002). The remaining sediment was dried 
again at $60^{\circ} \mathrm{C}$, and all samples were then sieved through an AFNOR succession series of meshes $(2000,1400,630,500,250,180,125,100$, and $63 \mu \mathrm{m})$. The following granulometric fractions were observed: gravel (GR, >2 mm), very coarse sand (VCS, 2-1 mm), coarse sand (CS, 1-0.5 mm) medium sand (MS, 0.5-0.25 mm), fine sand (FS, 0.25-0.125), and silt + clay $(>0.063 \mathrm{~mm})$. Median grain size $\left(\mathrm{Q}_{50}\right)$ was determined for each sample and sediment types were characterized according to Chassé \& Glémarec (1976). Sediments in the study area were exclusively sandy, ranging from coarse to fine sand (Table 1, Fig. 2).

TABLE 1. Coordinates and sediment type of nine sampling sites from Sidi Daoud, Tunisia.

\begin{tabular}{lllllllll}
\hline Site & Position N & Position E & $\begin{array}{l}\text { Depth } \\
(\mathbf{m})\end{array}$ & $\begin{array}{l}\text { Gravel } \\
(\boldsymbol{\%})\end{array}$ & $\begin{array}{l}\text { Sand } \\
(\boldsymbol{\%})\end{array}$ & $\begin{array}{l}\text { Silt } \\
(\boldsymbol{\%})\end{array}$ & $\begin{array}{l}\text { Q50 } \\
(\mathbf{m m})\end{array}$ & Sediment type \\
\hline $\mathbf{1}$ & $37^{\circ} 00^{\prime} 07^{\prime \prime}$ & $10^{\circ} 50^{\prime} 04^{\prime \prime}$ & 45 & 7.66 & 69.16 & 23.18 & 0.20 & Fine sand \\
$\mathbf{2}$ & $37^{\circ} 00^{\prime} 07^{\prime \prime}$ & $10^{\circ} 52^{\prime} 01^{\prime \prime}$ & 20 & 0 & 99.94 & 0.06 & 0.18 & Fine sand \\
$\mathbf{3}$ & $37^{\circ} 02^{\prime} 13^{\prime \prime}$ & $10^{\circ} 49^{\prime} 56^{\prime \prime}$ & 60 & 7.6 & 51.12 & 41.28 & 0.39 & Medium sand \\
$\mathbf{A}$ & $37^{\circ} 00^{\prime} 21^{\prime \prime}$ & $10^{\circ} 53^{\prime} 03^{\prime \prime}$ & 17.5 & 25.5 & 73.3 & 0.2 & 1.05 & Coarse sand \\
$\mathbf{B}$ & $37^{\circ} 00^{\prime} 11^{\prime \prime}$ & $10^{\circ} 53^{\prime} 37^{\prime \prime}$ & 3.9 & 1.7 & 97 & 1.3 & 0.70 & Coarse sand \\
$\mathbf{C}$ & $37^{\circ} 00^{\prime} 05^{\prime \prime}$ & $10^{\circ} 53^{\prime} 19^{\prime \prime}$ & 2 & 1.9 & 95.9 & 2.2 & 0.70 & Coarse sand \\
$\mathbf{D}$ & $37^{\circ} 03^{\prime} 04^{\prime \prime}$ & $10^{\circ} 58^{\prime} 13^{\prime \prime}$ & 5.7 & 60.6 & 37.4 & 2 & 0.40 & Medium sand \\
$\mathbf{E}$ & $37^{\circ} 03^{\prime} 18^{\prime \prime}$ & $10^{\circ} 58^{\prime} 00^{\prime \prime}$ & 3 & 0.2 & 99.79 & 0.01 & 0.30 & Medium sand \\
$\mathbf{H}$ & $37^{\circ} 02^{\prime} 19^{\prime \prime}$ & $10^{\circ} 54^{\prime} 27^{\prime \prime}$ & 2.5 & 1.3 & 98.7 & 0 & 0.17 & Fine Sand \\
\hline
\end{tabular}

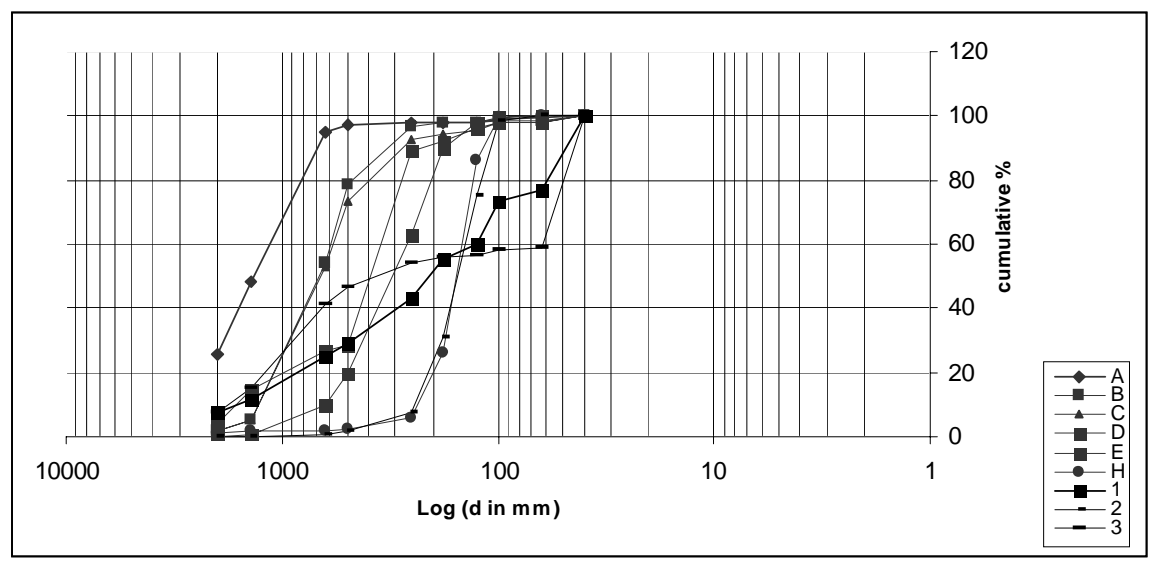

FIGURE 2. Cumulative curves for each sediment sample of the nine sites from Sidi Daoud, Tunisia.

Data analyses. An index was calculated for each sample for abundance of polychaetes (N), species richness (S), the Shannon-Weaver diversity index $\mathrm{H}^{\prime}\left(\log _{2}\right)$ (Shannon \& Weaver 1963) and Pielou's evenness J' (Pielou 1966). Rank-Frequency Diagrams (Frontier 1976) were proposed to study the community structure, based on two criteria: (1) the abundance of species and (2) the rank of species. RFD was originally applied to show temporal succession in a zooplankton community, but have since been used in spatio-temporal macrobenthic studies (Davoult 1992).

The DIMO, DIversity MOdel proposed by Quinghong (1995) was used to represent species richness $\left(\log _{2} \mathrm{~S}\right)$, Pielou's evenness, and the Shannon-Weaver diversity index $\left(\mathrm{H}^{\prime}\right)$ in a two- 
dimensional space. The faunal composition of shallow-water and deep-water sites in different seasons was compared using the Jaccard index and cluster analysis based on the similarity between stations in different seasons using the software PRIMER v6 (Clarke \& Gorley 2005). A dendrogram was produced using Bray-Curtis similarity (Bray \& Curtis 1957) and according to the following algorithm recommended by Lance \& Williams (1967):

dh $\mathrm{ij}=0.625 \mathrm{dh} \mathrm{I}+0.625 \mathrm{dh} \mathrm{j}-\beta \operatorname{dij}$ (with $\alpha=0.625$ and $\beta=0$ ).

\section{Results}

Polychaetes collected in the peninsula of Cap Bon yielded a total of 5,920 individuals belonging to 88 species and 29 families (Appendix 1), of which 29 species (33\%) are new records for the Tunisian fauna. New records belong to four families, six genera, and 29 species. The new families are Paraonidae with six species [Aricidea assimilis (Tebble, 1959); A. cerrutii (Laubier, 1966); A. fragilis mediterranea Laubier \& Ramos, 1974; Paradoneis armata Glémarec, 1966; P. harpagonea (Storck, 1967), and P. lyra (Southern, 1914)], Protodrilidae [Protodrilus purpureus (Schneider, 1868)], Saccocirridae (Saccocirrus papillocercus Bobretzky, 1871), and Paralacydonidae (Paralacydonia paradoxa Fauvel, 1913). The new genera reported for Tunisia are Armandia (A. polyphthalma Kükenthal, 1887); Galathowenia [G. oculata (Zaks, 1922)]; Isolda (I. pulchella F. Müller, 1858); Metasychis [M. gotoi (Izuka, 1902)]; Parathelepus [P. collaris (Southern, 1914)]; Parapionosyllis [P. gestans (Pierantoni, 1903); P. minuta (Pierantoni, 1903) and P. papillosa (Pierantoni, 1903)], and Polycirrus haematodes (Claparède, 1864). Other species newly reported for Tunisia are Aphelochaeta cf. marioni (Saint-Joseph, 1894); Caulleriella cf. alata (Southern, 1914); C. killariensis (Southern, 1914); Chaetozone cf. caputesocis (Saint-Joseph, 1894); C. gibber (Woodham \& Chamberlin, 1994); Eunice schizobranchia Claparède, 1870; Glycera capitata Oersted, 1843; G. lapidum Quatrefages, 1866; Harmothoe lunulata (Delle Chiaje, 1841); Pista maculata Marenzeller, 1884 and Protodorvillea atlantica (McIntosh, 1885). Genera represented by only one species are Kefersteinia cirrata (Keferstein, 1862), Paralacydonia paradoxa Fauvel, 1913; Protodrilus purpureus (Schneider, 1868); Saccocirrus papillocercus Bobretzky, 1871 and Terebellides cf. stroemi Sars, 1835.

The Dorvilleidae had the highest number of individuals in shallow water during autumn and spring, with $62 \%$ and $30 \%$, respectively. In deep water, Maldanidae and Onuphidae were the most abundant in autumn with $17 \%$ and $15 \%$, respectively, of the total abundance. In summer, the Onuphidae and Capitellidae were dominant with $21 \%$ and $17 \%$, respectively, of the total abundance (Fig. 3).

The number of polychaete species per site in different seasons ranged from 1 (site E) to 22 (site $\mathrm{H}$ ). The maximum abundance of polychaetes was found at site $\mathrm{C}$ in autumn and spring (Table 2), when the dorvilleid (Protodorvillea kefersteini) was dominant.

TABLE 2. Species richness $(S)$ and abundance $(N)$ for each sampling site in autumn (Au), spring (SP), and summer $(\mathrm{Su})$ for the polychaetes from Sidi Daoud, Tunisia.

\begin{tabular}{llllllllll}
\hline Sites & \multicolumn{1}{c}{$\mathbf{1}$} & \multicolumn{1}{c}{$\mathbf{2}$} & \multicolumn{1}{c}{$\mathbf{3}$} & \multicolumn{1}{c}{$\mathbf{A}$} & \multicolumn{1}{c}{ B } & \multicolumn{1}{c}{$\mathbf{C}$} & \multicolumn{1}{c}{ D } & \multicolumn{1}{c}{ E } & \multicolumn{1}{c}{ H } \\
\hline $\mathbf{N}$ & $60(\mathrm{Su})$ & 400 & $310(\mathrm{Su})$ & $40(\mathrm{Sp})$ & $120(\mathrm{Sp})$ & $950(\mathrm{Sp})$ & 550 & $10(\mathrm{Sp})$ & $520(\mathrm{Sp})$ \\
& $480(\mathrm{Au})$ & $(\mathrm{Su})$ & $520(\mathrm{Au})$ & $140(\mathrm{Au})$ & $190(\mathrm{Au})$ & $1250(\mathrm{Au})$ & $(\mathrm{Sp})$ & $10(\mathrm{Au})$ & $280(\mathrm{Au})$ \\
& & $50(\mathrm{Au})$ & & & & & $40(\mathrm{Au})$ & & \\
$\mathbf{S}$ & $4(\mathrm{Su})$ & $19(\mathrm{Su})$ & $14(\mathrm{Su})$ & $4(\mathrm{Sp})$ & $6(\mathrm{Sp})$ & $7(\mathrm{Sp})$ & $6(\mathrm{Sp})$ & $1(\mathrm{Sp})$ & $22(\mathrm{Sp})$ \\
& $22(\mathrm{Au})$ & $4(\mathrm{Au})$ & $18(\mathrm{Au})$ & $4(\mathrm{Au})$ & $7(\mathrm{Au})$ & $10(\mathrm{Au})$ & $2(\mathrm{Au})$ & $1(\mathrm{Au})$ & $17(\mathrm{Au})$ \\
\hline
\end{tabular}


Two distinct groups of species are shown by cluster analysis with each having an average similarity higher than $50 \%$ (Fig. 4). The first group includes the all coastal sites in spring (Csp) and autumn $(C a)$, and the second group includes the deeper sites in summer $(D s u)$ and autumn $(D a)$. The first group $\mathrm{Ca}$-Csp is composed of three stations with a coarse sand bottom (A-C), two sites with medium sand (D-E) and one site with fine sand $(\mathrm{H})$. This group is characterized by species such as $P$. kefersteini (1,030 $\mathrm{m}^{-2}$ in autumn) and Malacoceros fuliginosus $\left(400 \mathrm{~m}^{-2}\right.$ in spring). The second group consists of three deep sites with fine (sites 1-2) and medium sand (site 3). This group of sites had lower abundance and species richness (Table 3), and was characterized by Aponuphis fauveli in summer and Euclymene palermitana in autumn.

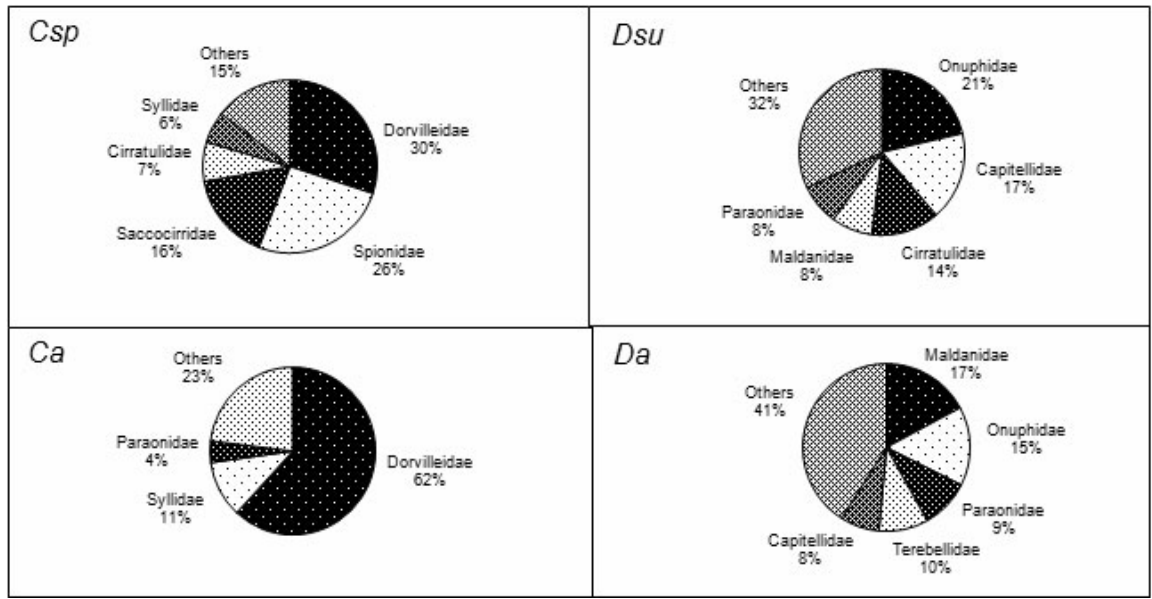

FIGURE 3. Polychaete family distribution from Sidi Daoud, Tunisia. Csp, coastal sites in spring; $C a$, coastal sites in autumn; $D s u$, deep-water sites in summer; $D a$, deep-water sites in autumn.

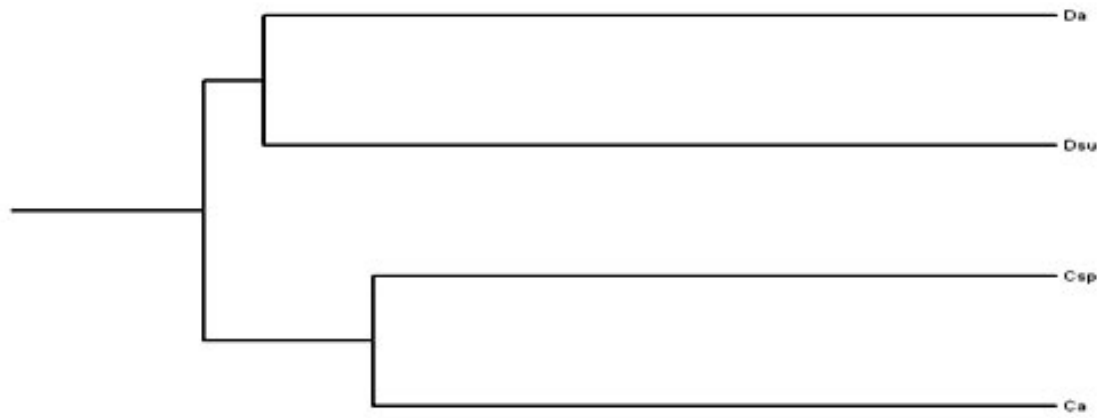

0. $\%$ Simatarity

50 .

100

FIGURE 4. Result of the cluster analysis with the 88 species of polychaetes collected from Sidi Daoud, Tunisia. $\mathrm{Ca}$, coastal sites in autumn; Csp, coastal sites in spring; Da, deeper sites in autumn; Dsu, deeper sites in summer. 
The rank/frequency diagrams show the spatial and temporal differences between communities and represent a powerful tool to study community structure and its evolution toward successional stages (1, 2, and 3), defined by Rhoads \& Germano (1982) as a transition from a stressed community with opportunistic species to a healthy community. The diagrams for the deep sites (Fig. 5A) from summer $(D s u)$ and autumn $(D a)$ show a progressive straightening of the curves with a shift towards stage 3 corresponding to an equilibrium state (Frontier 1976) dominated by infaunal deposit-feeders Some of these species are tubiculous (e.g., the polychaete family Maldanidae) but many others are mobile and free-living (Rhoads \& Germano 1982).
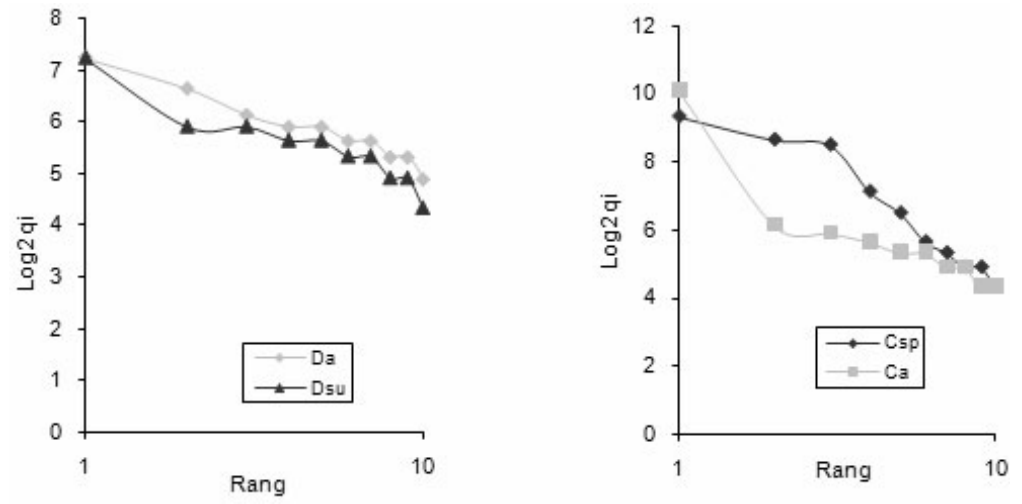

FIGURE 5. Rank/frequency diagrams for the polychaetes from Sidi Daoud, Tunisia. A, deep-water sites; B, shallow-water sites.

This change is marked by an increase in species richness and diversity $\left(\mathrm{H}^{\prime}=3.53\right.$ and $\mathrm{H}^{\prime}=4.07$, Table 3). In shallow water sites (Fig. 5B), the community in autumn showed a stage 1 succession characterized by a pioneering community with the opportunistic Protodorvillea kefersteini as the dominant species (1,090 individuals) and the lowest value of the Shannon index $\left(\mathrm{H}^{\prime}=2.61\right.$, Table 3). In spring, the stage 1 continued with an increase in Shannon diversity $\left(\mathrm{H}^{\prime}=3.05\right)$ and proliferation of other opportunistic polychaetes such as Malacoceros fuliginosus and Chaetozone gibber. These small opportunistic polychaetes are among one of the first macrofaunal component to colonize a new or newly disturbed bottom (Rhoads \& Germano 1982).

TABLE 3. Main characteristics of the polychaetes from Sidi Daoud, Tunisia. Abreviations: Csp, coastal sites in spring; Ca, coastal sites in autumn; Dsu, deep-water sites in summer; Da, deep-water sites in autumn; S, Species richness; N, abundance; H', Shannon-Weaver diversity; J', Pielou's evenness.

\begin{tabular}{|c|c|c|c|c|}
\hline \multirow{2}{*}{$\begin{array}{l}\text { Sites } \\
\text { Season }\end{array}$} & \multicolumn{2}{|c|}{ Ca-Csp $(A, B, C, D, E, H)$} & \multicolumn{2}{|c|}{ Da-Dsu $(1,2,3)$} \\
\hline & Autumn & Spring & Autumn & Summer \\
\hline $\begin{array}{l}\text { Dominant } \\
\text { species }\end{array}$ & $\begin{array}{l}\text { Protodorvillea } \\
\text { kefersteini }\end{array}$ & $\begin{array}{l}\text { Protodorvillea kefersteini } \\
\text { Malacoceros fuliginosus } \\
\text { Saccocirrus papillocercus } \\
\text { Chaetozone gibber }\end{array}$ & $\begin{array}{l}\text { Euclymene palermitana } \\
\text { Aponuphis fauveli } \\
\text { Aricidea assimilis }\end{array}$ & $\begin{array}{l}\text { Aponuphis } \\
\text { fauveli }\end{array}$ \\
\hline $\mathbf{S}$ & 36 & 36 & 34 & 27 \\
\hline $\mathbf{N}$ & 1900 & 2190 & 1050 & 770 \\
\hline $\mathbf{H}^{\prime}$ & 2.61 & 3.05 & 4.07 & 3.53 \\
\hline $\mathbf{J}^{\prime}$ & 0.58 & 0.71 & 0.92 & 0.93 \\
\hline
\end{tabular}


The DIMO model (Quinghong 1995) representing the three indices S, H', and J' (Fig. 6) confirms the results of cluster analysis and distinguishes two groups ( $C a-C s p$ and $D a-D s u)$. This model illustrates the transition from the shallow coastal sites to the deeper sites which is accompanied by an increase of Shannon diversity and Pielou's evenness. In the sites belonging to the same group (coastal or deep sites), the seasonal variations were also marked by an increase in Shannon diversity and Pielou's evenness.

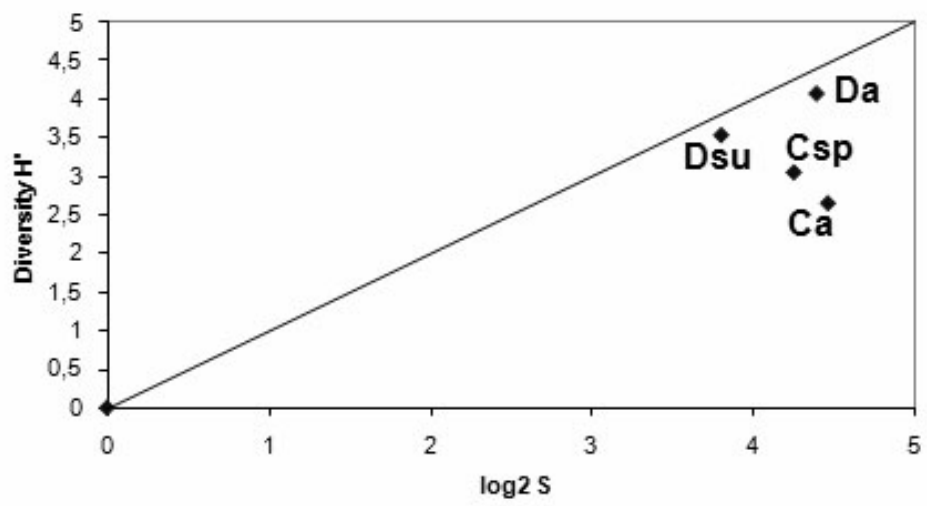

FIGURE 6. Position of different site groups according to the species richness and the diversity index $\mathrm{H}^{\prime}$; the diagonal line represent the maximum Pielou's evenness $\left(\mathbf{J}^{\prime}=1\right)$ for the polychaetes from Sidi Daoud, Tunisia.

\section{Discussion}

\section{Comparison with polychaete fauna of Tunisia}

Cantone (1978) reported 73 species of polychaetes in the Tunisian gulf in three different intertidal and infralittoral environments: Posidonia rhizomes, Caulerpa, and sandy shore. The species richness encountered in Sidi Daoud is similar to the results of Ayari \& Afli (2003), who found 89 species of polychaetes in Tunis Bay. They defined three communities: (1) the heterogeneous sediments with higher species richness dominated by Glycera convoluta and Lumbrineris fragilis; (2) the muddy sediments characterized by a high abundance of Melinna palmata; and (3) the sandy sediments, limited to the harbor area of Rades, which was relatively poor faunistically and dominated by the capitellid Notomastus latericeus. Zaâbi \& Afli (2005) studied the structure of polychaete assemblages along the northeastern coast of the Tunis Gulf. They listed 82 polychaetes species in three groups: (1) sandy and muddy sediments dominated by Chaetozone cf. setosa had the most species but the fewest individuals ( 58 species, $808 \mathrm{ind} . / \mathrm{m}^{2}$ ); (2) the fine sand dominated by Aricidea jeffreysii and Nephtys caeca had fewer species but more individuals (45 species, $1833 \mathrm{ind} . / \mathrm{m}^{2}$ ); and (3) the muddy sediments dominated by Melinna palmata had the fewest species and an intermediate number of individuals (19 species, $\left.1240 \mathrm{ind} . / \mathrm{m}^{2}\right)$.

In the present paper, the distribution of polychaete families showed that tubiculous worms such as Aponuphis fauveli and Euclymene palermitana dominated the deeper sites with sandy substrates; in shallow sites, opportunistic polychaetes like Protodorvillea kefersteini and Malacoceros fuliginosus were abundant. The fine substrate is favorable for the settlement of tubiculous polychaetes as the main constituent for tube building in agglomerated sand. This is the case for 
carnivorous species that hide from predators in tubes such as the onuphid A. fauveli. Differences in species composition between the deep and shallow sites can be related to sediment characteristics, including their texture and organic matter content (Pérès 1961). Simboura et al. (2000) also considered the type of substrate and the hydrodynamics as major factors controlling polychaete distribution in shallow waters. Numerous other authors have also insisted on the importance of bathymetric factors (Bellan 1964; Bhaud \& Bouteiller-Bougnol 1980).

The lowest values of species richness were found in shallow sites D-E in spring and autumn. These sites are situated in a small area of Sidi Daoud harbor in shallow water (Table 1) in front of an industrial discharge. The sediment is medium sand characterized by an abundance of gastropods shells and the absence of any type of vegetation. At the shallow sites, $70 \%$ of the total abundance was represented by four species: P. kefersteini, M. fuliginosus, Saccocirrus papillocercus, and Chaetozone gibber. We note the dominance of the opportunistic polychaete, M. fuliginosus (370 individuals in spring), which is considered an indicator of pollution (Bellan \& Pérès 1970; RebzaniZahaf 1992). In spite of high species richness (Table 3), the shallow site group had the minimum values of Shannon diversity $\left(\mathrm{H}^{\prime}=2.61\right.$ in autumn and $\mathrm{H}^{\prime}=3.05$ in spring, indicating moderate pollution $\left(3<\mathrm{H}^{\prime} \leq 4\right)$ according to Simboura \& Zenetos (2002). The low diversity values at these sites testify to the dominance of a limited group of polychaete species with high abundance (RebzaniZahaf 1992). The Pielou's evenness threshold $\left(0.80 \geq \mathbf{J}^{\prime}>0.65\right)$ for macrobenthic communities according to Daget (1976) and Glémarec \& Hily (1981), strengthen this conclusion. These results are similar to those found by Zaâbi \& Afli (2006) for a disturbed site (IB2) in the Sidi Daoud area. This is probably due to organic enrichment resulting from industrial discharges (Ben Charrada 1997).

\section{Comparison with polychaete fauna of Mediterranean Sea}

The analysis of polychaetes of Sidi Daoud shows that the area is diverse with 88 species, of which 29 species $(33 \%)$ are new records for the coasts of Tunisia. Four families are new for the Tunisian coasts: Paralacydoniidae, Paraonidae, Protodrillidae, and Saccocirridae. The paraonids are already well known from the Mediterranean Sea (Laubier \& Ramos 1973). The other new families (Paralacydoniidae, Protodrilidae, and Saccocirridae) were found in the Mediterranean Sea in Italy (Castelli et al. 1995), Spain (Moreira et al. 2006), and Algeria (Rebzani-Zahaf 1992), respectively. Some of the newly recorded species are common elsewhere in the Mediterranean Sea including species of Metasychis Light, 1991; Isolda O.F. Müller, 1858, and Parapionosyllis Fauvel, 1923. The species M. gotoi (Izuka, 1902) has been found in Croatia (Gillet 1988), in Italy (Castelli et al. 1995), and in the Aegean Sea (Ergen et al. 2006). The absence of some species in previous studies could be due to the Lessepsian migrant status of some species such as M. gotoi (Ergen et al. 2006).

In a checklist of the Italian fauna the estimated number of polychaetes is 803 species (Castelli et al. 1995). In a study of collections from the Aegean Sea and a literature review, Arvanitidis (2000) estimated that 592 polychaete species were present. More recently, Dauvin et al. (2006) recorded 641 Mediterranean species on the French coast including 1,700 km along the Mediterranean Sea. Zghal \& Ben Amor (1980) collected data concerning Tunisian polychaetes species and listed 222 species. The last inventory of polychaetes from the Tunisian coast was made by Ben Amor (1984) with 379 polychaete species. The present work adds 29 new species for a new total of 408 polychaete species from 1,300 km of the Tunisian coastline. The ratio of species (S) to coast length $(\mathrm{C})$ is good for Tunisia, with a value of $\mathrm{S} / \mathrm{C}=0.31$, which falls between the ratios for France $(0.38)$ and Italy $(0.11)$. The Tunisian coast is at the limit of the Western Mediterranean ( 884 polychaetes species) and the Central Mediterranean (528 polychaetes species) (Arvanitidis et al. 2002). The polychaete fauna of Tunisia includes $46 \%$ of the West Mediterranean species and $77 \%$ of the Central Mediterranean species. 


\section{Acknowledgments}

This work is part of the research framework MORGEN (Modèle et Outils de Recherche sur les Gisements des Ecosystèmes coralligènes du Nord). We are much indebted to the personnel of the R/ V "HANNIBAL" and our colleagues Chaouch Mohamed and Othmen Afif for their help in sampling and treating benthic samples. We are also grateful to the anonymous reviewers for their reviewing, advising, and critical comments on the manuscript.

\section{References}

Afli, A. \& Chenier, F. (2002) Etat de santé de la macrofaune benthique et rôle des espèces invasives dans le golfe du Morbihan (Bretagne, France). Vie et Milieu, 52 (1), 43-57.

Arvanitidis, C. (2000) Polychaete fauna of the Aegean Sea: inventory and new information. Bulletin of Marine Science, 66 (1), 73-96.

Arvanitidis, C., Bellan, G., Drakopoulos, P., Valavanis, V., Dounas, C., Koukouras, A. \& Eleftheriou, A. (2002) seascape biodiversity patterns along the Mediterranean and the Black Sea : lessons from the biogeography of benthic polychaetes. Marine Ecology Progress Series, 244, 139-152.

Ayari, R. \& Afli, A. (2003) Bionomie benthique de petit golfe de Tunis. Bulletin Institut National des Sciences et Technologie de la mer, Salammbô, 30, 79-90.

Azzouz, A. (1971) Des biocénoses benthiques et de la faune ichtyologique des fonds chalutables de la Tunisie, région nord et sud Est. Doctoral Thesis, 213 pp.

Bellan, G. (1964) Contribution à l'étude systématique, bionomique et écologique des Annélides Polychètes de la Méditerranée. Recueil des Travaux de la station marine d'Endoume, 49 (33), 1-351.

Bellan, G. \& Pérès, J.M. (1970) Etat général des pollutions sur les côtes Méditerranéennes de France. Estratto da Quaderni delle Civica Stazione Idrobiologica di Milano Maggio, 1, 36-65.

Ben Alaya, H. (1972) Répartition et condition d'installation de Posidonia oceanica Delile et Cymodocea nodosa Asheron dans le golfe de Tunis. Bulletin Institut National des Sciences et Technologie de la mer, Salammbô, 2 (3), 1-31.

Ben Amor, Z. (1984) Faune des polychètes de Tunisie. Faculté des sciences de Tunis, 237 pp.

Ben Charrada, R. (1997) Etude hydrodynamique et écologique du complexe petit golfe-lac de Tunis. Contribution à la modélisation de l'écosystème pélagique des eaux côtières - petit golfe de Tunis. Doctoral Thesis, 384 pp.

Ben Mustapha, K., Boury-Esnault, N., El Abed, A., Zarrouk, S. \& Souissi, A. (2003) Liste des éponges signalées à ce jour en Tunisie. Bulletin Institut National des Sciences et Technologie de la mer, Salammbô, 30, 56-57.

Bhaud, M. \& Le Bouteiller-Bougnol, C. (1980) Remarques sur les facteurs de répartition bathymétrique de deux Annélides Polychètes. Vie et Milieu, 30 (1), 19-28.

Bouderesque, C.F. (1997) La diversité biologique marine et lagunaire en Tunisie (état de connaissances actuelles, recommandations pour une stratégie nationale de conservation et d'utilisation durable). Partie 2: Situation de la biodiversité marine et lagunaire en Tunisie, UNEP, RAC/SPA, 1-127.

Bray, J.R. \& Curtis, J.T. (1957) An ordination of upland forest community of Southern Wisconsin. Ecological Monographs, 27, 325-349.

Cantone, G. (1978) Ricerche sui policheti della Tunisia. Animalia, 5, 51-78.

Castelli, A., Abbiati, M., Badalamenti, F., Bianchi, C.N., Cantone, G., Gambi, M.C., Giangrande, A. Gravina, M.F., Lanera, P., Lardicci, C., Somaschini, A. \& Sordino, P. (1995) Annelida Polychaeta, Pogonophora, Echiura, Sipuncula. In: Minelli, A., Ruffo, S. \& La Posta, S. (Eds.), Checklist delle species della fauna italiana, Bologna (Calderini), Italy, 19, 1-45.

Chassé, C. \& Glemarec, M. (1976) Atlas des fonds meubles du plateau continental du golfe de Gascogne. Cartes biosédimentaires, Editions I. C. A. Brest, $10 \mathrm{pp}$. 
Clarke, K.R. \& Gorley, R.N. (2005) PRIMER v6: User Manual/Tutorial. PRIMER-E, Plymouth.

Daget T.J. 1976. Les méthodes mathématiques en écologie. Masson, Paris, 172 pp.

Dauvin, J.C., Bachelet, G. \& Bellan, G. (2006) Biodiversity and biogeography relationships of the polychaete fauna in French Atlantic and Mediterranean waters. In: Sardà, R., San Martin, G., López, E., Martin, D. \& George, D. (Eds.), Scientific Advances in Polychaete Research. Scientia Marina, 70S3, 259-267.

Davoult, D. (1992) Choix raisonné de l'effort d'échantillonnage lors de l'étude spatiale de peuplements macrobenthiques. Comptes Rendus Académie des Sciences de Paris, 315, Série III, 279-285.

Ergen, Z., Cinar, M.E., Dagli, E. \& Kurt, G. (2006) Seasonal dynamics of soft-bottom polychaetes in Izmir Bay (Aegean Sea, eastern Mediterranean). In: Sardà, R., San Martin, G., López, E., Martin, D. \& George, D. (Eds.), Scientific Advances in Polychaete Research. Scientia Marina, 70S3, 197-207.

Fauchald, K. (1977) The polychaete worms. Definitions and keys to the order, families and genera. Natural History Museum of Los Angeles County Science Series 28: 1-188.

Fauvel, P. (1923) Polychètes errantes. Faune de France, Lechevalier, Paris, 16, 448 pp.

Fauvel, P. (1924a) Perinereis macropus (Claparède) var. canodanta, n. var. et genre Perinereis. Bulletin Société Zoologique France, 49, 389-394.

Fauvel, P. (1924b) Sur l'Aricia foetida, Claparède et ses variétés. Bulletin Société Zoologique France, 49, 518-528.

Fauvel, P. (1927) Polychètes sédentaires. Faune de France, Lechevalier, Paris, 16, 494 pp.

Frontier, S. (1976) Utilisation des diagrammes rangs fréquences dans l'analyse des écosystèmes. Journal Recherche Oceanographique, 1, 35-48.

Gillet, P. (1988) Annélides Polychètes des Fonds Meubles du Canal de Lim près de Rovinj (Yousgolavie). Thalassia Jugoslavica, 21/22, 1/2, 127-138.

Glémarec, M. \& Hilly, C. (1981) Perturbations apportées à la macrofaune benthique de la baie de Concarneau par les effluents urbains et portuaires. Acta Oecologica, 2 (2), 139-150.

Lance, G.N. \& Williams, W.T. (1967) A general theory of classificatory sorting strategies. Computer Journal, 9, $51-60$.

Laubier, L. \& Ramos, J. (1973) Paraonidae (Polychètes sédentaires) de Méditerranée. Bulletin du Muséum d'Histoire Naturelle, France, 113, 1097-1148.

Lubet, P. \& Azzouz, A. (1969) Etude des fonds chalutables du golfe de Tunis. Bulletin Institut National des Sciences et Technologie de la mer, 3, 87-111.

Mestiri, M., Ramos, A., Ben Mustapha, K. \& Ben Romdhane, M.S. (2005) Contribution à l'inventaire des Ascidies (Chordata: Ascidiacea) du parc marin de Zembra-Zembretta (nord Tunisie). Bulletin Institut National des Sciences et Technologie de la mer, 32, 45-51.

Moreira, J., Quintas, P. \& Troncoso, J.S. (2006) Spatial distribution of soft-bottom polychaete annelids in the Ensenada de Baiona (Ría de Vigo, Galicia, north-west Spain). In: Sardà, R., San Martin, G., López, E., Martin, D. \& George, D. (Eds.), Scientific advances in polychaete research. Scientia Marina, 70S3, 217-224.

Pérès, J.M. (1961) Océanographie biologique et biologie marine. Vol. 1, La vie benthique, Presses Universitaires de France, Paris. 541 pp.

Pielou, E.C. (1966) Shannon's formula as a measure of specific diversity: its use and measure. American Naturalist, 100, 463-465.

Quinghong, L. (1995) A model for species diversity monitoring at community level and its application. Environmental Monitoring and Assessment, 34, 271-284.

Rebzani-Zahaf, C. (1992) Le peuplement macrobenthique du port d'Alger: impact de la pollution. Hydroécologie Appliquée, 4 (2), 91-103.

Rhoads, D.C. \& Germano, J.D. (1982) Characterization of organism-sediment relations using sediment profile imaging: an efficient method of remote ecological monitoring of the seafloor (Remots ${ }^{\mathrm{TM}}$ System). Marine Ecology Progress Series, 8, 115-128.

Shannon, C. \& Weaver, W. (1963) The mathematical theory of communication. University Illinois Press, Urbana, Illinois, $117 \mathrm{pp}$.

Simboura, N. \& Zenetos, A. (2002) Benthic indicators to use in ecological quality classification of Mediterranean 
soft bottom marine ecosystems, including a new biotic index. Mediterranean Marine Science, 3, 2, 77-111.

Simboura, N., Nicolaidou, A. \& Thessalou-Legaki, M. (2000) Polychaete communities of Greece: An ecological overview. P.S.Z.N: Marine Ecology, 21, 129-144.

Westheide, W. (1972) La faune des Polychètes et des Archiannélides dans les plages à Ressac de la côte méditerranéenne de la Tunisie. Bulletin Institut National des Sciences et Technologie de la mer, 2 (3), 449-468.

Zaâbi, S. \& Afli, A. (2005) Structure générale des peuplements d'annélides polychètes dans le secteur nord-est du golfe de Tunis. Bulletin Institut National des Sciences et Technologie de la mer, 32, 53-58.

Zaâbi, S. \& Afli, A. (2006) Signification écologique de la variabilité des polychètes dans le golfe de Tunis. Bulletin Institut National des Sciences et Technologie de la mer, 33, 29-36.

Zaouali, J. \& Baeten, S. (1985) Etude des peuplements d'animaux macrobenthiques de la zone centrale et du bassin oriental de la mer des Bibans (Tunisie méridionale) par la méthode de l'analyse factorielle des correspondances. Rapports de la CIESM, 29 (4), 199-203.

Zghal, F. \& Azzouna, A. (1982) Annélides Polychètes de Tunisie. Revue de la Faculté des Sciences de Tunis, 2 , $115-120$.

Zghal, F. \& Ben Amor, Z. (1980) Annélides polychètes de Tunisie. Bulletin de l'Office National de Pêches de Tunisie, IV (1), 1-11.

Zibrowius, H. (1970-1971) Les espèces Méditerranéennes du genre Hydroides (Polychaeta, Serpulidae): remarque sur le prétendu polymorphisme de Hydroides uncinata. Tethys, 2 (3), 691-746. 
APPENDIX 1. List of species found in Sidi Daoud (northeast coast of Tunisia).

\begin{tabular}{|c|c|c|c|c|c|c|c|c|c|}
\hline \multirow{2}{*}{ Species } & \multicolumn{9}{|c|}{ Sampling Stations } \\
\hline & 1 & 2 & 3 & $\mathbf{A}$ & B & $\mathbf{C}$ & D & $\mathbf{E}$ & $\mathbf{H}$ \\
\hline Amphicteis gunneri (M. Sars, 1835) & $\mathbf{x}$ & & & & & & & & \\
\hline Amphitritides gracilis (Grube, 1860) & $\mathbf{x}$ & & & & & & & & \\
\hline Aonides oxycephala (Sars, 1862) & & & & & & & & & $\mathbf{x}$ \\
\hline Aphelochaeta cf. marioni (Saint-Joseph, 1894) & $\mathbf{x}$ & $\mathbf{x}$ & $\mathbf{x}$ & & & & & & \\
\hline Aponuphis brementi (Fauvel, 1870) & & & & & & & & & $\mathbf{x}$ \\
\hline Aponuphis fauveli (Rioja, 1918) & $\mathbf{x}$ & $\mathbf{x}$ & $\mathbf{x}$ & & & $\mathbf{x}$ & & & \\
\hline Arabella iricolor (Montagu, 1804) & & & & & & & & & $\mathbf{x}$ \\
\hline Aricidea assimilis Tebble, 1959 & $\mathbf{x}$ & & $\mathbf{x}$ & & & & & & \\
\hline Aricidea cerrutii Laubier, 1966 & & & & & $\mathbf{x}$ & & & & $\mathbf{x}$ \\
\hline Aricidea fragilis Webster, 1879 & $\mathbf{x}$ & $\mathbf{x}$ & $\mathbf{x}$ & & & & & & \\
\hline Armandia polyphtalma (Dujardin, 1839) & & & & & $\mathbf{x}$ & $\mathbf{x}$ & & & \\
\hline Brada villosa (Rathke, 1843) & & & & & & & & & $\mathbf{x}$ \\
\hline Caulleriella cf. alata (Southern, 1914) & & $\mathbf{x}$ & & & & & & & \\
\hline Caulleriella bioculata (Keferstein, 1862) & & & & $\mathbf{x}$ & & $\mathbf{x}$ & $\mathbf{x}$ & & \\
\hline Caulleriella killariensis (Southern, 1914) & $\mathbf{x}$ & & & & & & & & \\
\hline Chaetozone cf. caputesocis (Saint-Joseph, 1894) & & $\mathbf{x}$ & & & & & & & $\mathbf{x}$ \\
\hline Chaetozone gibber Woodham \& Chamberlin, 1994 & $\mathbf{x}$ & & & & & & & & $\mathbf{x}$ \\
\hline Chone duneri Malmgren, 1867 & & & & & & & & & $\mathbf{x}$ \\
\hline Diopatra neapolitana Delle Chiaje, 1841 & $\mathbf{x}$ & & $\mathbf{x}$ & & & & & & $\mathbf{x}$ \\
\hline Dodecaceria concharum Örsted, 1843 & & $\mathbf{x}$ & & & & & & & \\
\hline Dorvillea atlantica (McIntosh, 1885) & & & & & & $\mathbf{x}$ & & $\mathbf{x}$ & \\
\hline Drilonereis filum (Claparede, 1870) & & & $\mathbf{x}$ & & & & & & $\mathbf{x}$ \\
\hline Eteone longa (Fabricius, 1780) & & & & $\mathbf{x}$ & & & & & \\
\hline Euclymene palermitana (Grube, 1840) & $\mathbf{x}$ & & $\mathbf{x}$ & & & & & & \\
\hline Eunice schizobranchia Claparède, 1870 & $\mathbf{x}$ & & & & & & & & \\
\hline Eunice vittata (Delle Chiaje, 1828) & $\mathbf{x}$ & & $\mathbf{x}$ & $\mathbf{x}$ & & & & & \\
\hline Galathowenia oculata (Zaks, 1922) & $\mathbf{x}$ & & & & & & & & \\
\hline Glycera alba (O. F. Müller, 1776) & & & $\mathbf{x}$ & & & & & & \\
\hline Glycera capitata Örsted, 1843 & & $\mathbf{x}$ & & & & & & & \\
\hline Glycera convoluta Keferstein, 1862 & & $\mathbf{x}$ & & & & & & & $\mathbf{x}$ \\
\hline Glycera lapidum Quatrefages, 1866 & & & & & & $\mathbf{x}$ & & & \\
\hline Salvatoria limbata (Claparède, 1868) & & & & & $\mathbf{x}$ & & & & \\
\hline Malmgreniella lunulata (Delle Chiaje, 1828) & & & & & & & & & $\mathbf{x}$ \\
\hline Harmothoe sp. Kinberg, 1855 & & & & $\mathbf{x}$ & & $\mathbf{x}$ & & & \\
\hline Hyalinoecia tubicola (O. F. Müller, 1776) & $\mathbf{x}$ & & & & & & & & \\
\hline Isolda pulchella F. Müller, 1858 & & & $\mathbf{x}$ & & & & & & \\
\hline Kefersteinia cirrata (Keferstein, 1862) & & & & $\mathbf{x}$ & $\mathbf{x}$ & & & & $\mathbf{x}$ \\
\hline Websterinereis glauca (Claparède, 1870) & & & & $\mathbf{x}$ & & & & & \\
\hline Lumbrineris fragilis (O. F. Müller, 1776) & & $\mathbf{x}$ & & & & & & & \\
\hline
\end{tabular}


APPENDIX (continued)

\section{Species}

Sampling Stations

Lumbrineris impatiens (Claparède, 1868)

Lumbrineris latreilli Audouin and Milne-Edwards, 1834

Lumbrineris paradoxa Saint-Joseph, 1888

Lysidice ninetta Audouin \& Milne Edwards, 1833

Magelona rosea Moore, 1907

Malacoceros fuliginosus (Claparède, 1869)

Maldane glebifex Grube, 1860

Marphysa belli Audouin \& Milne-Edwards, 1833

Metasychis gotoi (Izuka, 1902)

Naineris laevigata (Grube, 1855)

Nematonereis unicornis Schmarda, 1861

Nephtys caeca (Fabricius, 1780)

Notomastus profundus Eisig, 1887

Notomastus latericeus M. Sars, 1851

Ophelia limacina (Rathke, 1843)

Owenia fusiformis Delle Chiaje, 1841

Paradoneis armata Glemarec, 1966

Paradoneis harpagonea (Storch, 1967)

Paradoneis lyra (Southern, 1914)

Paralacydonia paradoxa Fauvel, 1913

Parapionosyllis gestans (Pierantoni, 1903)

Parapionosyllis minuta (Pierantoni, 1903)

Parapionosyllis papillosa (Pierantoni, 1903)

Parathelepus collaris (Southern, 1914)

Piromis eruca (Claparède, 1870)

Pista cristata (O. F. Müller, 1776)

Pista elongata Moore, 1909

Platynereis dumerilii (Audouin \& Milne-Edwards, 1833)

Polycirrus haematodes (Claparède, 1864)

Polyphtalmus pictus (Dujardin, 1839)

Prionospio cf. cirrifera Wirén, 1883

Prionospio malmgreni Claparède, 1869

Protodorvillea kefersteini (McIntosh, 1869)

Protodrilus purpureus (Schneider, 1868)

Pseudomalacoceros contabra Rioja, 1919

Saccocirrus papillocercus Bobretzky, 1872

Scoloplos armiger (O. F. Müller, 1776)

Sphaerosyllis capensis Day, 1953

Sphaerosyllis hystrix Claparède, 1863
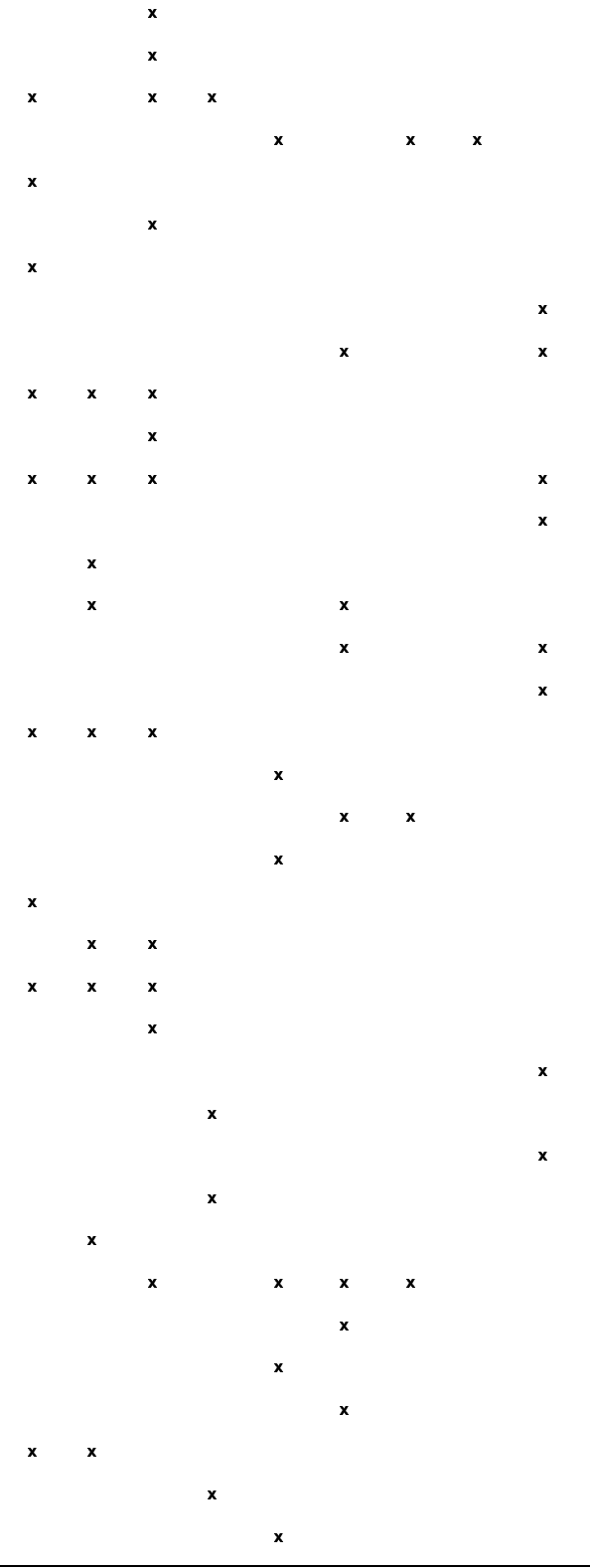

.....continued 
APPENDIX (continued)

\section{Species}

\section{Sampling Stations}

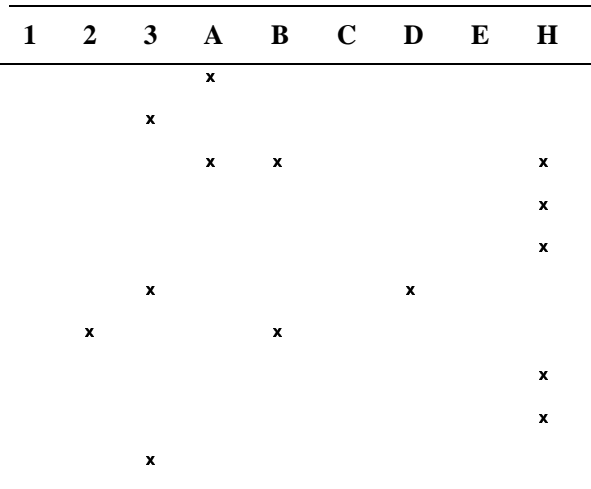

Spio filicornis (Müller, 1776)

Spio multioculata (Rioja, 1918)

Schistomeringos rudolphi (Delle Chiaje, 1882)

Syllis amica Quatrefages, 1866

Syllis armillaris (O. F. Müller, 1771)

Syllis cornuta Rathke, 1843

Syllis hyalina Grube, 1840

Syllis prolifera Krohn, 1852

Syllis variegata Grube, 1860

Terebellides cf. stroemi Sars, 1835 